Journal of Engineering Sciences, Assiut University, Vol. 38, No. 2, pp. 381-402, March, 2010.

\title{
EVALUATION OF SEISMIC PERFORMANCE OF MULTISTORY BUILDINGS DESIGNED ACCORDING TO EGYPTIAN CODE
}

\section{Khaled A. Abdel-Raheem ${ }^{1}$, Shehata E. Abdel Raheem ${ }^{2}$, Hosny M.Soghair ${ }^{3}$ and Mahmoud H. Ahmed ${ }^{4}$}

1. Demonstrator, Civil Engineering, Faculty of Engineering, Assiut University

2. Assoc. Prof. of Structural Engineering, Civil Engineering, Faculty of Engineering, Assiut University

3. Prof. of Reinforced Concrete, Dept Head, Civil Engineering, Faculty of Engineering, Assiut University

4. Prof. of Reinforced Concrete, Civil Engineering, Faculty of Engineering, Assiut University

(Received December 27, 2009 Accepted January 9, 2010)

The seismic response of building structures can be estimated by several analysis methods. Each approach incorporates different assumptions and varies in complexity of application. The traditional approach is to employ equivalent static analysis methods while current design practice is moving towards an increased emphasis on nonlinear analysis methods. This study examined the seismic performance of multistory buildings designed according to Egyptian code. Nonlinear time history analysis is used for evaluation of equivalent static and response spectra procedures that recommended by Egyptian codes for seismic design of building structures. In this study, a preliminary seismic response analysis of two buildings was performed using three analysis procedures to evaluate the building seismic performance and the difference in global response predicted by the three methods. Moreover, three analysis procedures are evaluated for their ability to predict deformation demands in terms of inter-story drifts and potential failure mechanisms. Three ground motions of earthquake records are used for seismic demands evaluation of these buildings. The results demonstrated that, for the three analysis methods used in this study, different predictions of seismic response occurred. Furthermore, the results of the analyses are used to evaluate the advantages, limitations, and ease of application of each approach for seismic analysis. Each method is shown to have merits and deficiencies that should be considered when selecting a seismic analysis method for a particular building structure.

KEYWORDS: Seismic design; Egyptian building code; time history analysis; Building lateral rigidity.

\section{INTRODUCTION}

Occurrences of recent earthquakes in different parts of the world and the resulting losses, especially human lives, have highlighted the structural inadequacy of buildings to carry 
seismic loads. There is an urgent need for assessment of existing buildings in terms of seismic performance and continuously upgrade the seismic codes for design of new buildings. On Monday, October 12, 1992, an earthquake hit Egypt in an area that has had no recent seismic activity. Earthquake physical damage was estimated at about one billion US dollars [1]. Since October 1992, a set of Egyptian codes have been released to prevent buildings collapse and/or control major damages of structural elements. The latest code was the Egyptian Code for Load and Forces (ECLF2008) released on November 2008. The ECLF2008, and most of the international participating building codes, depends on the traditional approach of equivalent static load method as a main method for evaluating seismic actions on symmetrical buildings [2]. For nonsymmetrical buildings, the ECLF2008 recommended the response spectrum method to be used for building seismic analysis/design, which considered more accurate method of analysis than the equivalent static load method [3].

It is expected that this comparative assessment of various analysis schemes will help identify the most essential procedure to evaluate seismic performance. The focus of this study is to assess the different methods of analysis, equivalent static load (ESL) and the response spectrum (RS). The specifications permit the designer to utilize a variety of methods for seismic analysis; from simple equivalent static analysis to complex nonlinear dynamic analysis. For building structures, it is common practice to utilize a simplified approach, such as equivalent static load (ESL). This approach has several shortcomings, which have been accepted due to its simplicity and a lack of alternative practical approaches. Such approach may be regarded as force-based since the methods primary emphasis is on the forces within the structure. In recent years, there has been a shift of attention away from linear methods of seismic analyses to nonlinear methods which put emphasis on the displacements within the structure. Thus, nonlinear analysis methods that are capable of realistically predicting the deformations imposed by earthquakes on structures are needed. In response to this need, nonlinear static analysis procedures have appeared in national resource documents such as the ATC-40 report on seismic evaluation and retrofit of concrete buildings and the FEMA-356 pre-standard on seismic rehabilitation of buildings. Such analysis methods are useful for predicting inelastic displacement capacities while simultaneously offering a compromise between the oversimplification of linear static analysis and the inherent complexity of nonlinear dynamic analysis.

This study aims to evaluate the way Egyptian Code 2008 treats the consideration of seismic loads/analysis methods during the seismic design of buildings, and to discuss the alternative solutions for cases wherein existing provisions do not lead to satisfactory results. The evaluation of Egyptian Code 2008 provisions and simplified methods is performed through comparison with a more refined approach whereas an effort is made to quantitatively assess the relative importance of various design and analysis assumptions. Nonlinear time history analysis has been performed to evaluate ESL and RS analysis methods. A set of three time history records has been used. The main objective is to assess the fundamental period, total base shear, displacements and story drifts for the three methods of analysis. The results show that, ESL method is overestimated and not accurate for calculating seismic action. The objective of this study is to evaluate various methods of analysis on seismic evaluation of existing buildings. The seismic action is a function of the building mass, stiffness and material damping [4]. However, ECLF2008 gives an empirical expression to calculate ESL seismic action 
depending on the total building weight only neglecting the effect of building stiffness and material damping on seismic action. To show the effect of the building lateral rigidity on seismic action, a different lateral and diaphragm rigidities have been analyzed. The results show that, the building rigidity and diaphragm rigidity have a significant effect on the shear and displacement demands calculated from response spectrum and nonlinear time history methods.

\section{DISCRIPTION OF BUILDING STRUCTURE AND FINITE ELEMENT MODEL}

\subsection{Building Description and Design}

Until the early 1980s, the conventional approach to earthquake design was to use a quasi-static method to determine the dynamic effects of seismic loading. Dynamic analysis software is now commonplace and various forms of dynamic analysis are now the norm. The generalized approach to dynamic analysis is to develop a model of the structural system and impose a time dependant input motion based on measurements of real earthquake motions. There are many methods available to solve this problem, ranging from elastic response spectra methods to nonlinear time history analysis incorporating soil structure interaction. Some models may need to account for soil behavior, material non-linearity, geometric non-linear effects, high levels of damping and other complex behavior. Thus seismic analysis presents a considerable challenge to the engineer. Many advances in earthquake engineering have been made from the observation of the performance of real structures that have been subject to a severe earthquake. Analytical modeling, including FEA, has an important role, but its limitations must be recognized. For many engineered structures, satisfactory seismic performance requires careful attention to analysis, design, and detailing and good construction practice. This is particularly so for buildings expected to undergo inelastic deformation. Safety is thus achieved by the successful integration of analysis, design and construction.

The building structural elements have been first designed according to Egyptian code of practice (ECP 203-2007) [6] under static loads assuming an un-cracked sections for beam and slabs in the analysis. The materials used in the design are C250 for concrete and St52 for steel (characteristic yield strength for steel of $3600 \mathrm{~kg} / \mathrm{cm}^{2}$ ). Square columns were used with different cross-sections to represent the change in lateral rigidity. Also, a different beams and slab cross-sections were used to represent the rigid diaphragm effect. These sections have been checked under seismic actions by using the Egyptian code for load and forces (ECLF 2008) [2] to satisfy the Egyptian code requirements taking into consideration the effect of earthquake loads. The minimum safe column cross-section under static and dynamic loads, to satisfy the Egyptian code requirements [19], is $45 \times 45$ for 6 -story building and $60 \times 60$ for 10 -story building.

The model is assumed to be a residential building with maximum live load of $200 \mathrm{~kg} / \mathrm{m}^{2}$. According to ECLF 2008, in case of residential buildings, the total effective seismic weight of the building, $W$, shall be taken equal to the total dead load of the building without taking any effect of live loads. SAP2000 analysis program automatically estimates the own weight of the structural elements and include it in the 
elastic and inelastic analysis [7]. Because of symmetry in both directions, the torsional effect has not taken into consideration at this case of modeling.

\subsection{Finite Element Model}

A three-dimensional mathematical model of the physical structure, Fig. 1, will be used that represents the spatial distribution of the mass and stiffness of the structure to an extent that is adequate for the calculation of the significant features of the building's dynamic response. Structural models shall incorporate realistic estimates of stiffness and damping considering the anticipated levels of excitation and damage. A multistory six bays frame model of a hypothetical reinforced concrete building has been analyzed using SAP2000 structural analysis software package [5]. The building is modeled as 3D frame structure using frame elements for columns, longitudinal beams and transverse beams and shell element for slabs with rigid floor diaphragms distribute uniformly the lateral loads on the vertical elements.

\section{SEISMIC ANALYSIS PROCEDURES}

To evaluate ECLF2008 and the effect of change in the building rigidity on seismic actions, three different methods have been used; the equivalent static lateral force method (ESL); the response spectrum method (RS) and the inelastic time history method (TH). Equivalent static lateral force method (ESL) does not take into consideration the effect of the change in building rigidity. Response spectrum method is more accurate than ESL method [3]. Also, time history method is considered as an exact solution for the two buildings which represent any change in the building properties.

\subsection{Equivalent static load (ESL) method}

According to ECLF 2008, the seismic base shear force, $F_{b}$; for each horizontal direction in which the building is analyzed, shall be determined using the following expression:

$F_{b}=\gamma S_{d}\left(T_{1}\right) \cdot \lambda \cdot W / g$
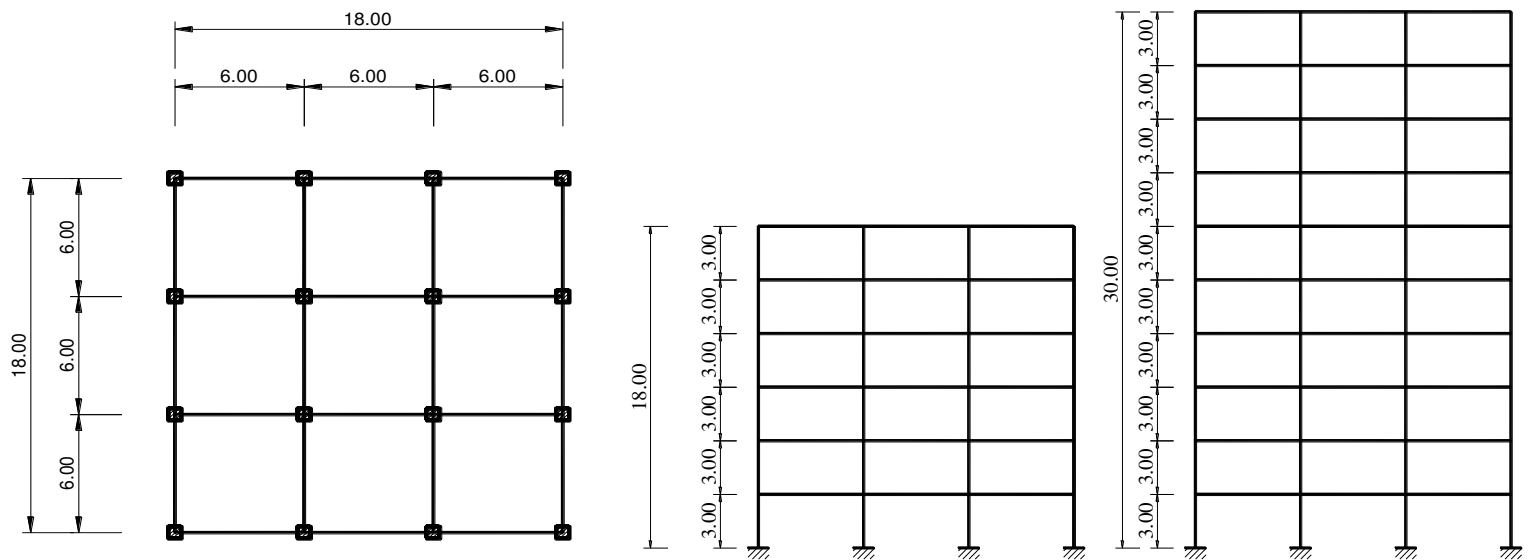

Typical Floor plan view

Elevation View

Fig.1 Model of 6-story and 10-story buildings 
Where: $S_{d}\left(T_{1}\right)$ is the ordinate of the design spectrum at period $T_{1} ; T_{1}$ is the fundamental period of vibration of the building for lateral motion in the direction considered; $W$ is the total weight of the building, above the foundation level; $g$ is the gravity acceleration; $\gamma$ is the importance factor of the building; $\lambda$ is the effective modal mass correction factor, the value of which is equal to: $\lambda=0.85$ for $T \leq 2 T_{\mathrm{C}}$, and $n>2$ stories. The value of the fundamental period of vibration, $T$, determined using the following expression:

$T=C_{t} \cdot H^{3 / 4}$

Where $C_{t}$ is a factor determined according to the structural system and building material and equal to 0.075 in case of moment-resistant space concrete frame; $H$ is the height of the building, in $\mathrm{m}$, from the foundation or from the top of a rigid basement. The ordinate of the design spectrum, $S_{d}\left(T_{1}\right)$, can be determinate from:

$$
S_{d}(T)=\frac{2.5}{R} a_{g} \cdot \gamma \cdot S \cdot \eta\left[\frac{T_{c}}{T}\right] \geq[0.20] a_{g} \gamma
$$

Where $a_{g}$ is the design ground acceleration for the reference return period; $T c$ is the upper limit of the period of the constant spectral acceleration branch (Fig. 2); $\eta$ is the design damping correction factor for the horizontal elastic response spectrum where a reference value of $\eta=1$ corresponds to a normal $5 \%$ viscous damping ratio (case of RC buildings); $S$ is the soil factor. $\gamma$ is the importance factor. $R$ is the reduction factor according the statical system of the structure.

The seismic zone considered in this study is zone 1 (for Assiut city) and the shape of spectrum is type 1(Fig. 2). The two models are considered as a residential buildings with importance factor $\gamma=1$. The soil is considered to be stiff soil, which presents soil class " $\mathrm{C}$ " and a soil factor $S=1.5$. The reduction factor, $R$, is taken considering the vertical loads and the total base shear are totally resisted by the frame structure without using shear walls or bracings $(R=6)$. It should be noted that, ECLF 2008 recommends that in the application of the ESFM method, the building should meet the criteria for regularity in both plan and elevation, and with calculated structural period $T$ not greater than $2 \mathrm{sec}$ or $4 T_{c}$ (1 sec for the selected soil class (class "C")).

In ESFM, according to ECLF 2008, the base shear is determinated as a percentage of the total building weight that gives a value of $17 \%$ of the total weight of the building in 6-story building and $20 \%$ in 10 -story building.

The total base shear, $F_{b}$, shall be determined by applying horizontal forces $F_{i}$ to each story mass $m_{i}$ and shall be distributed as follows:

$$
F_{i}=\left[\frac{z_{i} W_{i}}{\sum_{j=1, n} z_{j} W_{j}}\right] \cdot F_{b}
$$

Where $F_{i}$ is the horizontal force acting on story $i ; F_{b}$ is the seismic base shear force (Eq. 1); $z_{i}, z_{j}$ are the heights of the masses $m_{i}, m_{j}$ above the foundation level respectively; $W_{i}, W_{j}$ are the weights of masses $m_{i}, m_{j} ; n$ is the number of stories above foundation level. Eq. 4 gives a linear shear distribution depending only on the height of the story. 


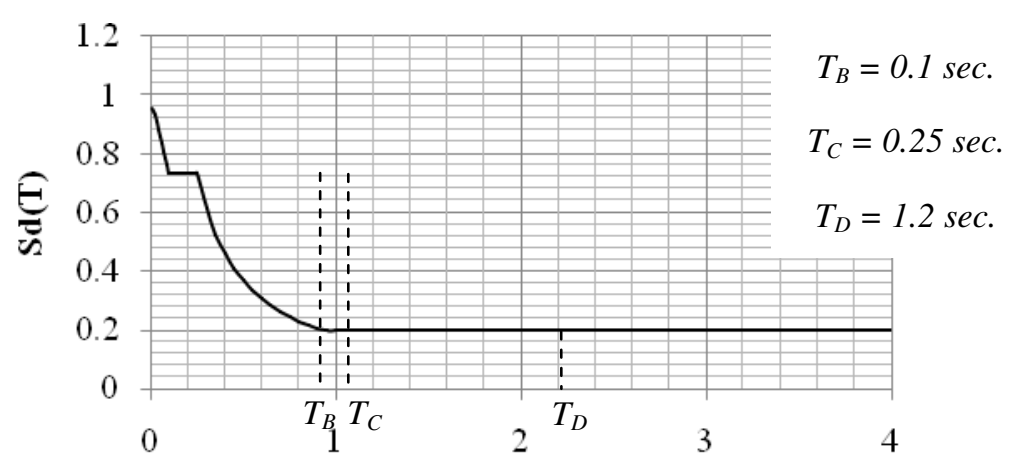

Time (sec)

Fig. 2 Design response spectrum for all regions of Egypt except coastal areas

\subsection{Response Spectrum (RS) Method}

Response spectrum analysis includes sufficient modes of vibration to capture participation of at least $90 \%$ of the structure's mass in each of two orthogonal directions [8]. To be able to compare the two methods of analysis (ESL and RS), the same data has been used in both methods including the seismic zone, soil class, importance factor and reduction factor. Fig. 2 shows the design response spectrum curve for current case of study. It shall be noted that, ECLF 2008 includes a damping coefficient in the elastic response spectra equations. Hence, no damping ratio has been used in the analysis of this method.

\subsection{Nonlinear Time History (TH) Method}

Nonlinear time-history analysis is by far the most comprehensive method for seismic analysis. The earthquake record in the form of time vs. acceleration is input at the base of the structure. The response of the structure is computed at each second (or even less) for the entire duration of an earthquake. This method differs from response spectrum analysis because the effect of "time" is considered. That is, stresses and deformations in the structure at an instant are considered as an initial boundary condition for computation of stresses in the next step. Furthermore, nonlinearities that commonly occur during an earthquake can be included in the time-history analysis. Such nonlinearities cannot be easily incorporated in response spectrum analysis. Unlike the response spectrum method, nonlinear time-history analysis does not assume a specific method for mode combination. Hence, results are realistic and not conservative. Furthermore, this method is equivalent to getting $100 \%$ mass participation using response spectrum analysis. Full mass participation is necessary to generate correct earthquake forces. Usually, only 90 95\% participation is obtained in response spectrum analysis. All types of nonlinearities can be accounted for in this analysis. This could be very important when seismic retrofit involves energy dissipation using yielding of members or plastic hinge rotation. However, this method is very expensive and time consuming to perform. Large amounts of information are generated. Furthermore, input earthquake is never known with certainty. Hence, three to five different histories are used, further increasing the cost. 
Since the results of the TH depends mainly on the characteristic of the used acceleration time-history records and the shapes of their corresponding elastic response spectra [9], the reason of using the inelastic TH method is to verify the results obtained by other code specific analysis procedures (ESL and RS methods) against a time-history record. Nonlinear time-history analysis was performed taking into consideration the $P-\Delta$ and large displacements effect. A constant damping ratio of 0.05 has been taken for both of RC buildings. The inelastic time-history analysis is preformed using the direct integration technique considering a time step of 0.005 second.

\subsection{Input Seismic Excitation}

A set of three records have been used in the analysis; the north-south component of the ground motion recorded at a site in El Centro, during the Imperial Valley, California, earthquake of May 18, 1940 [10] (TH1) and two natural records for Gulf of Aqaba, Egypt, earthquake of November 22, 1995 (TH2 and TH3)[11]. These earthquake records are shown in table 1 . The maximum acceleration value for these records was found to be $0.211 \mathrm{~g}, 0.014 \mathrm{~g}$ and $0.086 \mathrm{~g}$ for TH1, TH2 and TH3 respectively. The soil type of these earthquakes is stiff soil as considered in the analysis for both ESL and RS methods. To be able to compare the results with those obtained from ESL method, the three time history records (TH1, TH2 and TH3) scaled to PGA factor of $0.628 \mathrm{~g}, 9.25 \mathrm{~g}$ and $1.54 \mathrm{~g}$ respectively in case of 6-story building and $0.541 \mathrm{~g}, 8.15 \mathrm{~g}$ and $1.33 \mathrm{~g}$ respectively in case of 10-story building. Fig. 3 shows the design spectra adapted in ECLF2008, and the three scaled time history records used in the analysis.

The three methods are analyzed using SAP2000 (computer and structures). The structural analysis program SAP2000 [12] is a software package from Computers and Structures, which is based on the finite element method for modeling and analysis. Among the features introduced by the analysis engine of SAP2000 are eigenvalue analysis, static and dynamic analysis and linear and nonlinear analysis. For R/C buildings, constant material properties are used in SAP2000. These properties are: weight per unit volume $2.4028 \mathrm{tf} / \mathrm{m}^{3}$, mass per unit volume $0.245 \mathrm{t} / \mathrm{m}^{3}$ and modulus of

Table 1 Characteristics of time history acceleration records used in the analysis.

\begin{tabular}{c|c|c|c|c|c|c|c}
\hline Record & Earthquake & Station & $\begin{array}{c}\text { Compone } \\
\mathrm{nt}\end{array}$ & $\begin{array}{c}\text { PG } \\
\mathrm{A} \\
(\mathrm{g})\end{array}$ & $\begin{array}{c}\text { PGV } \\
(\mathrm{cm} / \\
\mathrm{s})\end{array}$ & $\begin{array}{c}\text { PGD } \\
(\mathrm{cm})\end{array}$ & $\begin{array}{c}\text { Local } \\
\text { Geology }\end{array}$ \\
\hline $\begin{array}{c}\text { El Centro } \\
(\mathrm{TH} 1)[10]\end{array}$ & $\begin{array}{c}\text { Imperial Valley } \\
1940 / 05 / 19 \\
04: 37\end{array}$ & $\begin{array}{c}\text { Impvall/ } \\
\text { I- } \\
\text { ELC270 }\end{array}$ & $\mathrm{N}-\mathrm{S}$ & $\begin{array}{c}0.21 \\
5\end{array}$ & 30.2 & 23.91 & Stiff Soil \\
\hline $\begin{array}{c}\text { AQABA- } \\
\mathrm{H}\end{array}$ & $\begin{array}{c}\text { Aqaba } \\
1995 / 11 / 22 \\
\text { (TH2)[11] }\end{array}$ & Hadera & $\mathrm{N}-\mathrm{S}$ & $\begin{array}{c}0.01 \\
4\end{array}$ & 2.1 & 0.65 & Stiff Soil \\
\hline $\begin{array}{c}\text { AQABA- } \\
\mathrm{E} \\
\text { (TH3)[11] }\end{array}$ & $\begin{array}{c}\text { Aqaba } \\
1995 / 11 / 22 \\
06: 16\end{array}$ & Eilat & $\mathrm{N}-\mathrm{S}$ & $\begin{array}{c}0.08 \\
6\end{array}$ & 10.6 & 4.39 & Stiff Soil \\
\hline
\end{tabular}

elasticity $2534563.6 \mathrm{t} / \mathrm{m}^{2}$. 
In SAP2000, it has been assumed that the floor diaphragms are rigid enough to distribute uniformly the lateral loads on the vertical elements. The out-of-plane deformations are absorbed by the rigid horizontal diaphragms and shear deformation effects are neglected. SAP2000 can specify for each material of one or more stress-strain curves that are used to generate inelastic properties in frame elements. The material used in the model buildings, RC, is characterized by the stress-strain curves in Fig.4, as modeled in SAP2000.

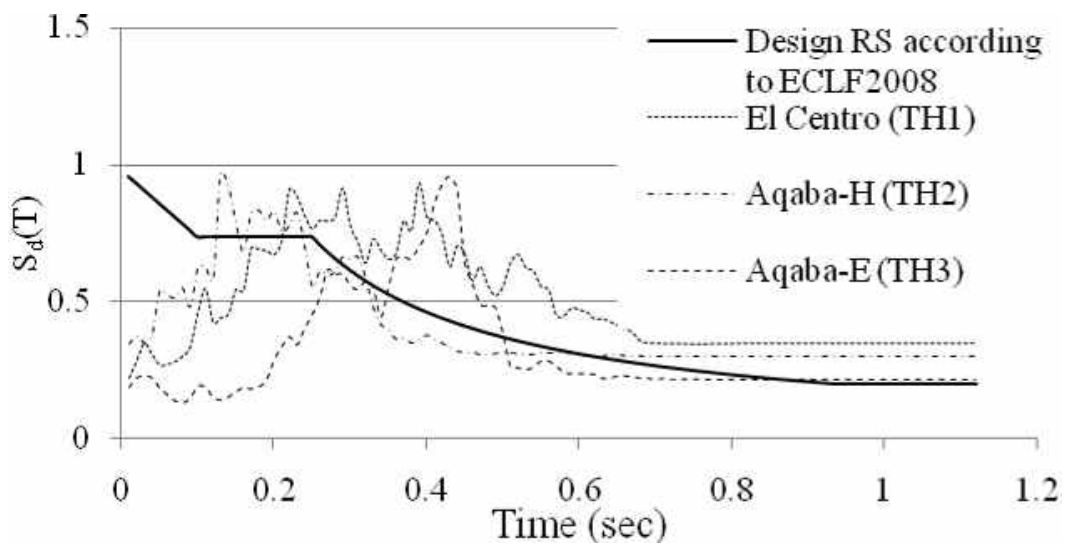

Fig. 3 Associated 5\%-damped response spectrum for the three records

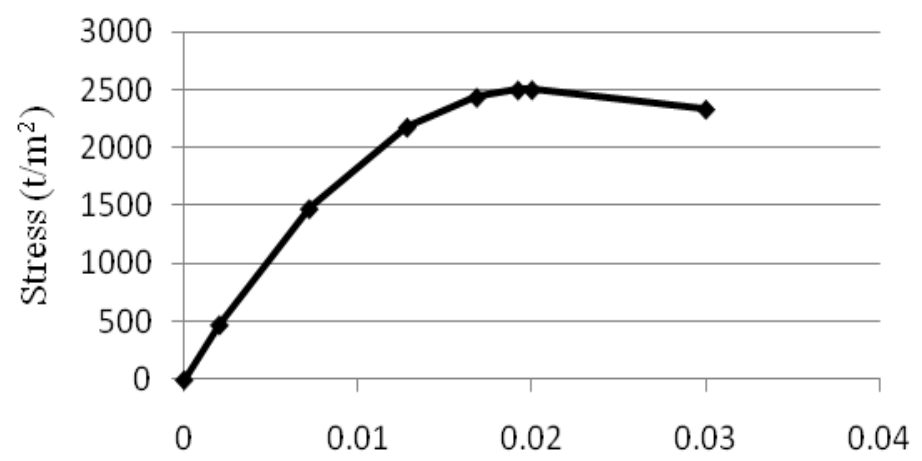

Strain

Fig. 4 Stress-strain curve for confined RC as modeled in SAP2000

\section{RESULTS AND DISCUSSIONS}

\subsection{Effect of Building Model Lateral Stiffness:}

The two models, 6-story and 10-story buildings, have been studied to evaluate the effect of the lateral rigidity on determination and evaluation of fundamental period, base shear, displacement and story drift. A constant beam and slab sections are considered in the analysis with different column cross-section to present the change in lateral rigidity. These cross-sections for different 7 models are enlarged in Table 2. 
Table 2 Building structural element dimensions for different lateral stiffness models

\begin{tabular}{|c|c|c|c|c|}
\hline & Model & Beam size $(\mathrm{cm})$ & Slab thickness $(\mathrm{cm})$ & Column $(\mathrm{cm})$ \\
\hline \multirow{3}{*}{$\begin{array}{l}\vec{D} \\
\text { क्. } \\
b\end{array}$} & Model Ls1 & $25 \times 70$ & 15 & $45 \times 45$ \\
\hline & Model Ls2 & $25 \times 70$ & 15 & $90 \times 90$ \\
\hline & Model Ls3 & $25 \times 70$ & 15 & $120 \times 120$ \\
\hline \multirow{4}{*}{$\begin{array}{l}\vec{D} \\
0 \\
0 \\
0 \\
0\end{array}$} & Model Ls4 & $25 \times 70$ & 15 & $60 \times 60$ \\
\hline & Model Ls5 & $25 \times 70$ & 15 & $90 \times 90$ \\
\hline & Model Ls6 & $25 \times 70$ & 15 & $120 \times 120$ \\
\hline & Model Ls7 & $25 \times 70$ & 15 & $180 \times 180$ \\
\hline
\end{tabular}

Table 3 Estimation of the fundamental period of the building for different lateral stiffness models

\begin{tabular}{|c|c|c|c|c|c|c|c|c|}
\hline \multirow[b]{3}{*}{ Code } & \multirow[b]{3}{*}{ Period, $T$} & \multicolumn{7}{|c|}{ Fundamental Period (sec) } \\
\hline & & \multicolumn{3}{|c|}{ 6-story } & \multicolumn{4}{|c|}{10 -story } \\
\hline & & $\begin{array}{c}\text { Mod } \\
\text { el } \\
\text { Ls1 }\end{array}$ & $\begin{array}{c}\text { Mod } \\
\text { el } \\
\text { Ls2 }\end{array}$ & $\begin{array}{c}\text { Mod } \\
\text { el } \\
\text { Ls3 }\end{array}$ & $\begin{array}{c}\text { Mod } \\
\text { el } \\
\text { Ls4 }\end{array}$ & $\begin{array}{c}\text { Mod } \\
\text { el } \\
\text { Ls5 }\end{array}$ & $\begin{array}{c}\text { Mod } \\
\text { el } \\
\text { Ls6 }\end{array}$ & $\begin{array}{l}\text { Mod } \\
\text { el } \\
\text { Lsa7 }\end{array}$ \\
\hline \multicolumn{2}{|c|}{$\begin{array}{l}\text { 3D model natural vibration } \\
\text { analysis, fundamental mode }\end{array}$} & 0.68 & 0.47 & 0.43 & 0.93 & 0.85 & 0.83 & $\begin{array}{c}0.77 \\
8\end{array}$ \\
\hline ECLF2008 [2] & $T_{c}=0.075 H^{3 / 4}$ & $\begin{array}{c}0.65 \\
5\end{array}$ & $\begin{array}{c}0.65 \\
5\end{array}$ & $\begin{array}{c}0.65 \\
5\end{array}$ & $\begin{array}{c}0.96 \\
1\end{array}$ & $\begin{array}{c}0.96 \\
1\end{array}$ & 0.96 & $\begin{array}{c}0.96 \\
1\end{array}$ \\
\hline ECLF 92 [14] & $T=0.1 \mathrm{~N}$ & 0.6 & 0.6 & 0.6 & 1 & 1 & 1 & 1 \\
\hline IBC [15] & $T=0.03 H^{3 / 4}$ & $\begin{array}{c}0.26 \\
2\end{array}$ & $\begin{array}{c}0.26 \\
2\end{array}$ & $\begin{array}{c}0.26 \\
2\end{array}$ & $\begin{array}{c}0.38 \\
5\end{array}$ & $\begin{array}{c}0.38 \\
5\end{array}$ & $\begin{array}{c}0.38 \\
5\end{array}$ & $\begin{array}{c}0.38 \\
5\end{array}$ \\
\hline UBC 97 [16] & $T=0.02 H^{3 / 4}$ & $\begin{array}{c}0.17 \\
5\end{array}$ & $\begin{array}{c}0.17 \\
5\end{array}$ & $\begin{array}{c}0.17 \\
5\end{array}$ & $\begin{array}{c}0.25 \\
6\end{array}$ & $\begin{array}{c}0.25 \\
6\end{array}$ & $\begin{array}{c}0.25 \\
6\end{array}$ & $\begin{array}{c}0.25 \\
6\end{array}$ \\
\hline EC8 [17] & $T=0.075 H^{3 / 4}$ & $\begin{array}{c}0.65 \\
5\end{array}$ & $\begin{array}{c}0.65 \\
5\end{array}$ & $\begin{array}{c}0.65 \\
5\end{array}$ & $\begin{array}{c}0.96 \\
1\end{array}$ & $\begin{array}{c}0.96 \\
1\end{array}$ & $\begin{array}{c}0.96 \\
1\end{array}$ & $\begin{array}{c}0.96 \\
1\end{array}$ \\
\hline $\begin{array}{l}\text { NBCC2005 } \\
{[18]}\end{array}$ & $T=0.05 H^{3 / 4}$ & $\begin{array}{c}0.43 \\
7\end{array}$ & $\begin{array}{c}0.43 \\
7\end{array}$ & $\begin{array}{c}0.43 \\
7\end{array}$ & $\begin{array}{c}0.64 \\
1\end{array}$ & $\begin{array}{c}0.64 \\
1\end{array}$ & $\begin{array}{c}0.64 \\
1\end{array}$ & $\begin{array}{c}0.64 \\
1\end{array}$ \\
\hline
\end{tabular}

Note: $H$ is the building height above the foundation level and $N$ is the number of the stories.

\subsubsection{Natural Vibration Analysis:}

The fundamental period of vibration, $T$, is a function of the stiffness of the lateral load resisting system and the building mass [13]. The fundamental period in ECLF 2008, $T_{c}$, does not influence by the change of the column cross-section but depends only on the building height. Table 3 presents different fundamental periods, for the buildings studied, as obtained from structural analysis and empirical expression in ECLF2008 and other international building codes using different lateral rigidity models. In both 6-story and 10 -story buildings, the periods computed from empirical expressions are significantly 
shorter than those computed from structural models except the empirical expressions adopted in ECLF2008 and EC8. In these codes, the fundamental period is almost the same compared with those computed from structural models.

Table 3 shows that, in case of relatively flexible columns (model Ls1 and model Ls4) the fundamental period calculated from ECLF2008 and the structural model is almost the same. The increase of the lateral rigidity decreases the value of the fundamental period (e.g. the fundamental period decreased by $36 \%$ in model Ls3 and by $19 \%$ in model Ls7). But the fundamental period estimated from ECLF2008, $T_{c}$, is constant. That means the ECLF2008 empirical expression for estimating the fundamental period is convenient in case of relatively flexible columns only and the fundamental period depends on lateral rigidity.

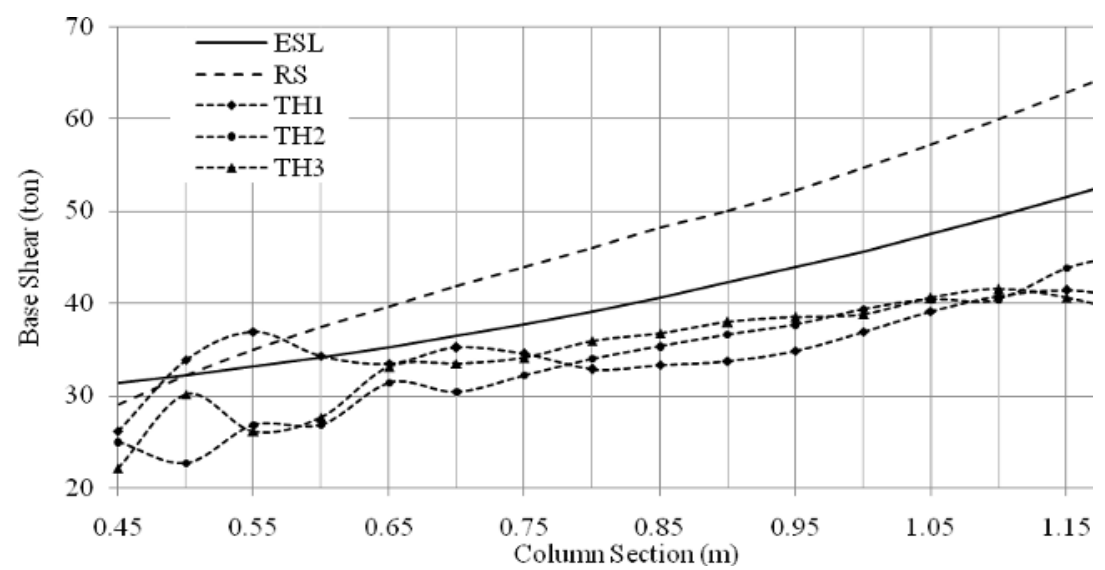

a) 6-story

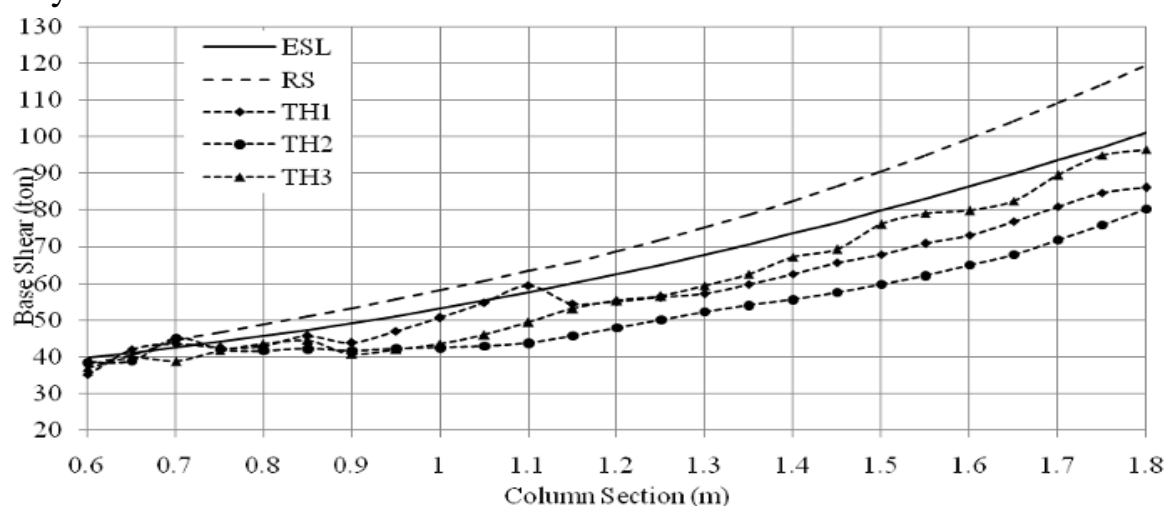

b) 10-story

Fig. 5 Total base shear calculated from different lateral rigidity

\subsubsection{Base Shear Demands for Different Lateral Stiffness Models}

The total base shear has been calculated for the two RC buildings using the three methods of analysis (ESL, RS and nonlinear TH), Fig.5. Once the ESL method depends only on the building weight, the increase of the lateral rigidity increases linearly the base shear. But the increase of the base shear calculated from RS method is significantly larger than that in ESL method (e.g. the increase in base shear from model Ls1 to model 
Ls3 is $44 \%$ calculated from ESL and $56 \%$ calculated from RS in case of 6-story building). That means the base shear does not depend only on the building weight. Fig. 5 shows that the base shear calculated from nonlinear time history method, for the three records, is significantly lower than that calculated from ESL and RS methods. That means, the methods adopted in ECLF2008, ESL and RS methods, are overestimated and gives a higher base shear compared with nonlinear time history method.

\subsubsection{Lateral Displacement and Drift Demands:}

To show the effect of the column rigidity on the shear distribution, the displacements and the story drifts in case of 6-story and 10-story buildings have been calculated using the three different methods of analysis (ESL, RS and average time history for the three records ATH) and shown in Figs. 6 and 7. It shall be noted that, the increase of the lateral rigidity does not mean a decrease of the column displacement because the displacement and the total base shear values increases with the increase of the lateral rigidity.
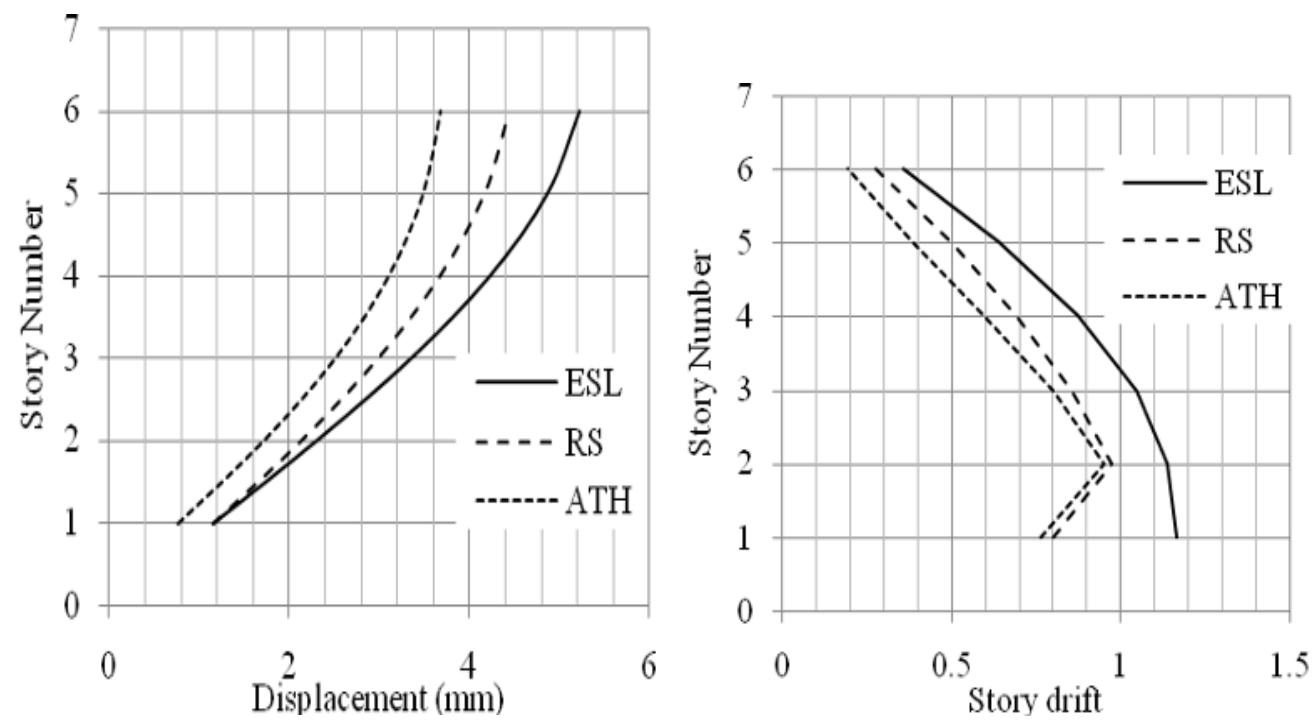

a) Model Ls1 


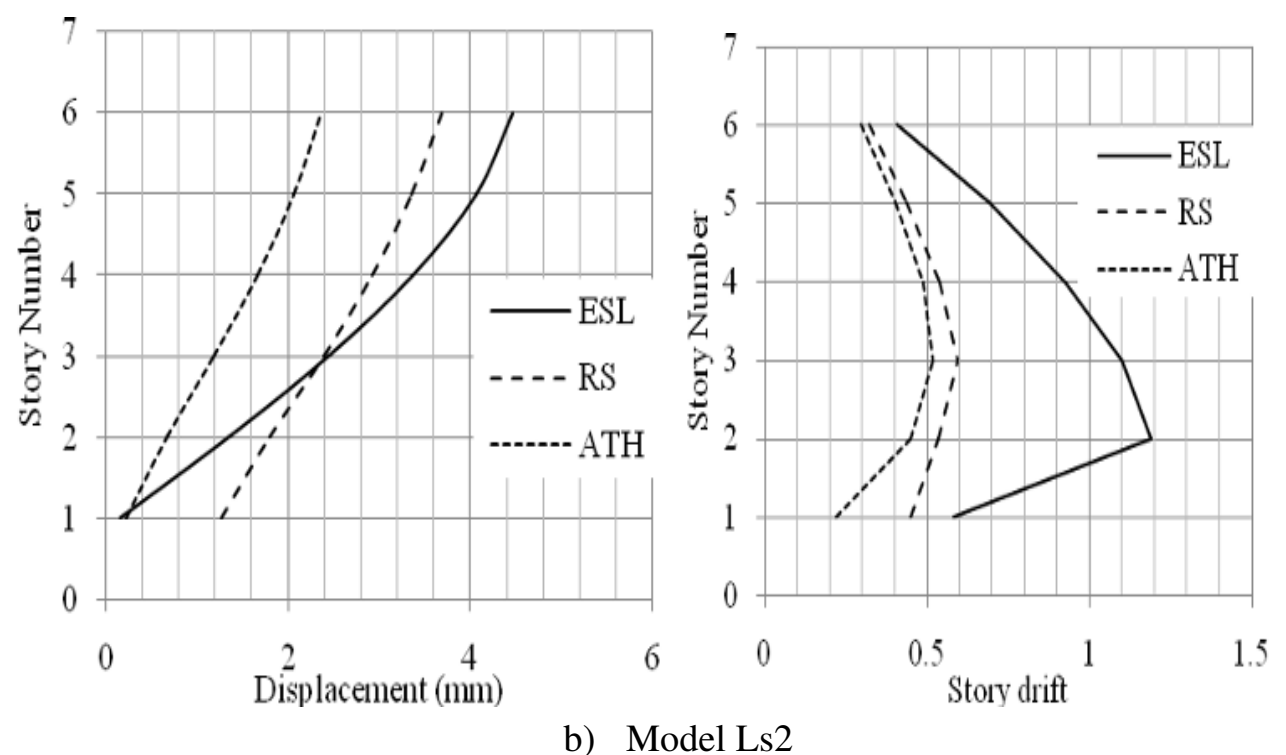

Fig. 6 Effect of lateral stiffness on displacements and story drift for 6-story models

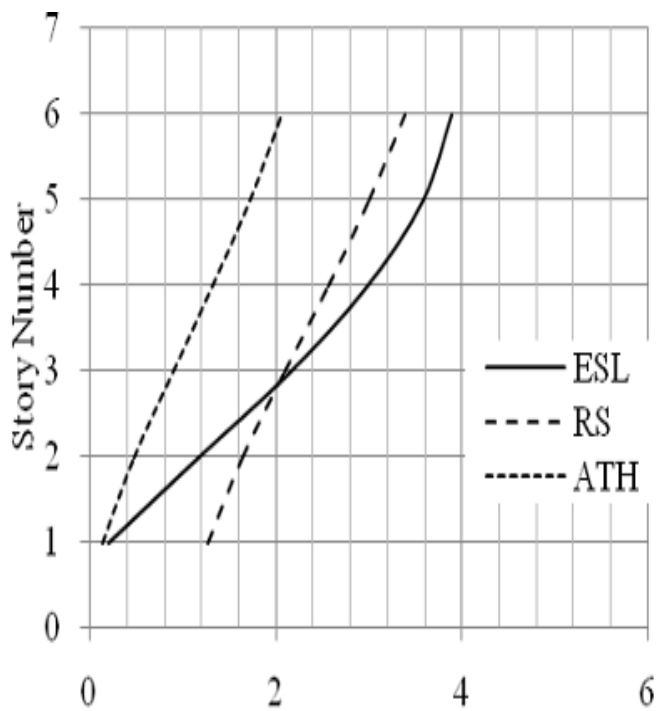

Displacement (mm)

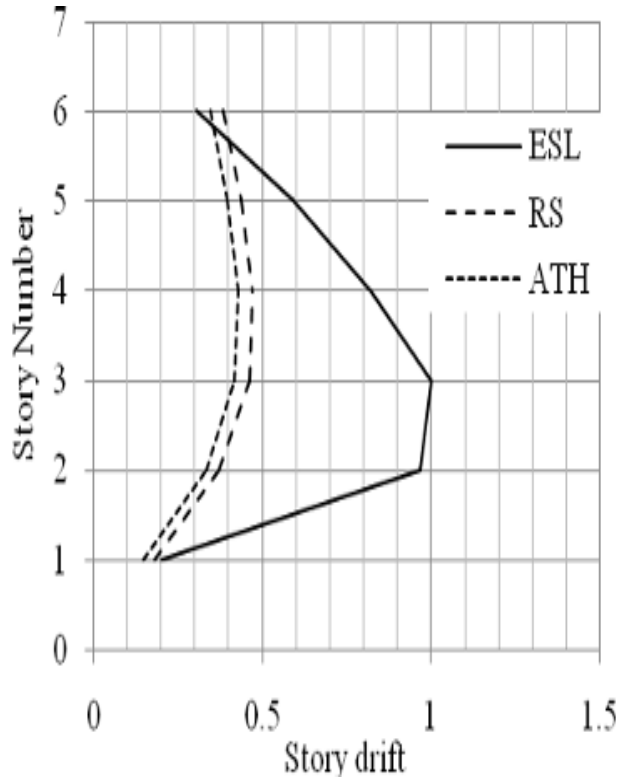

c) Model Ls3

Continue Fig. 6 Effect of lateral stiffness on displacements and story drift for 6-story models 

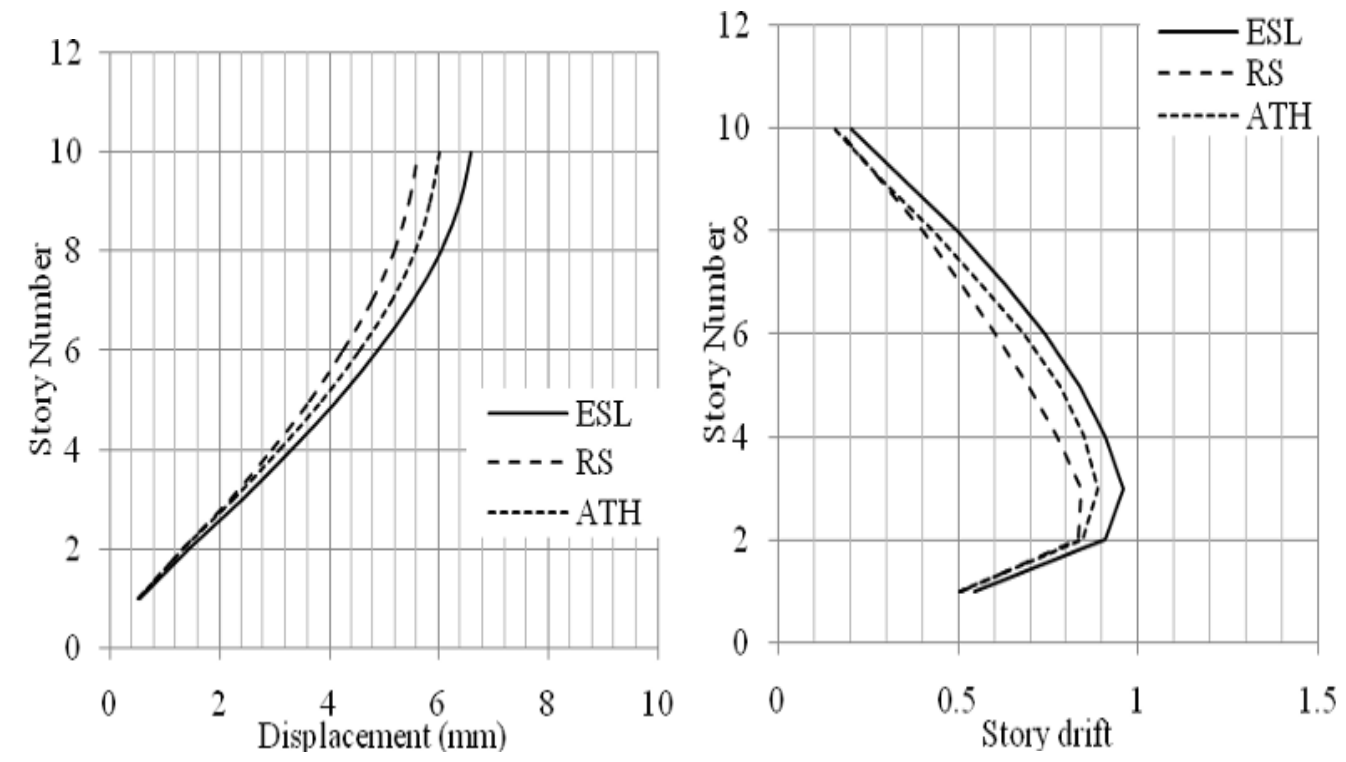

a) Model Ls4
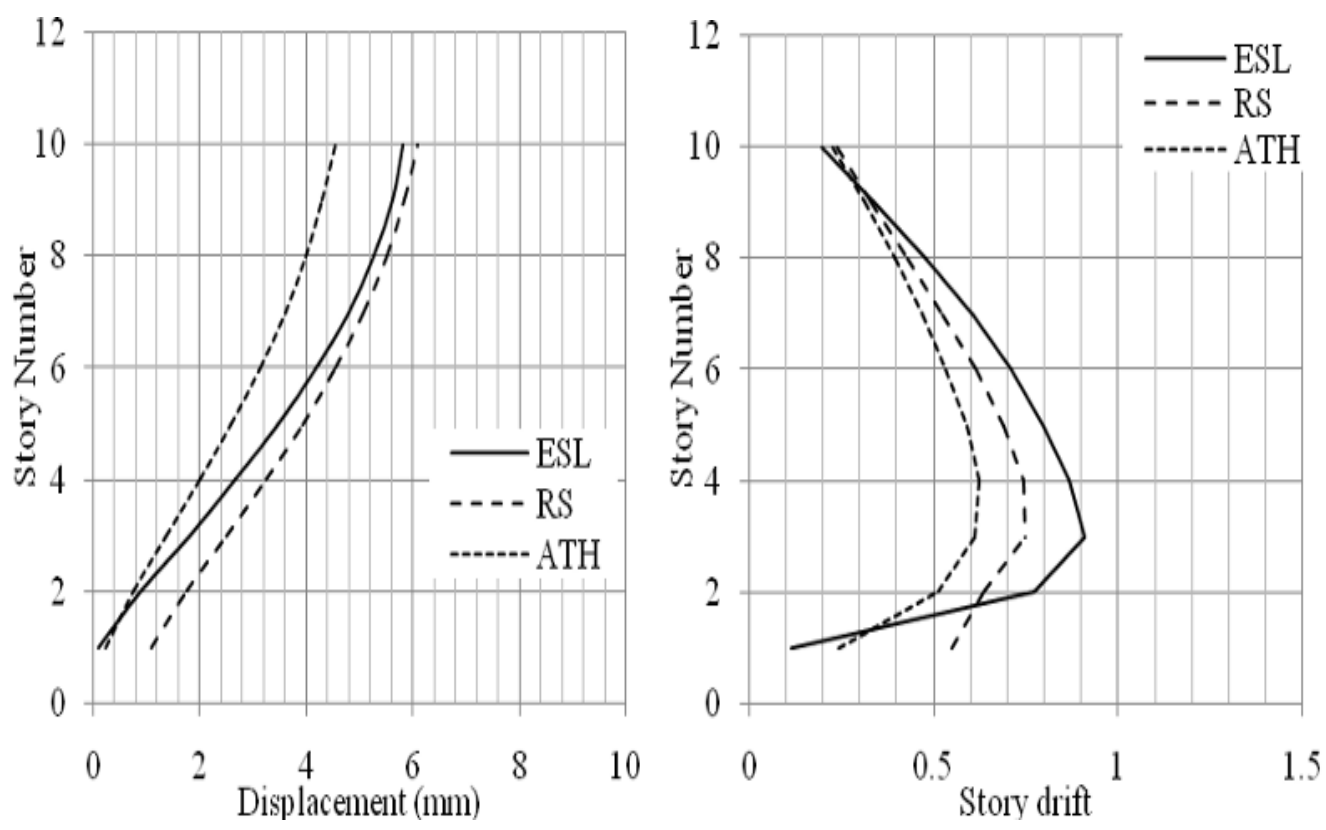

b) Model Ls5

Fig. 7 Effect of lateral stiffness on displacements and story drift for 10-story models 

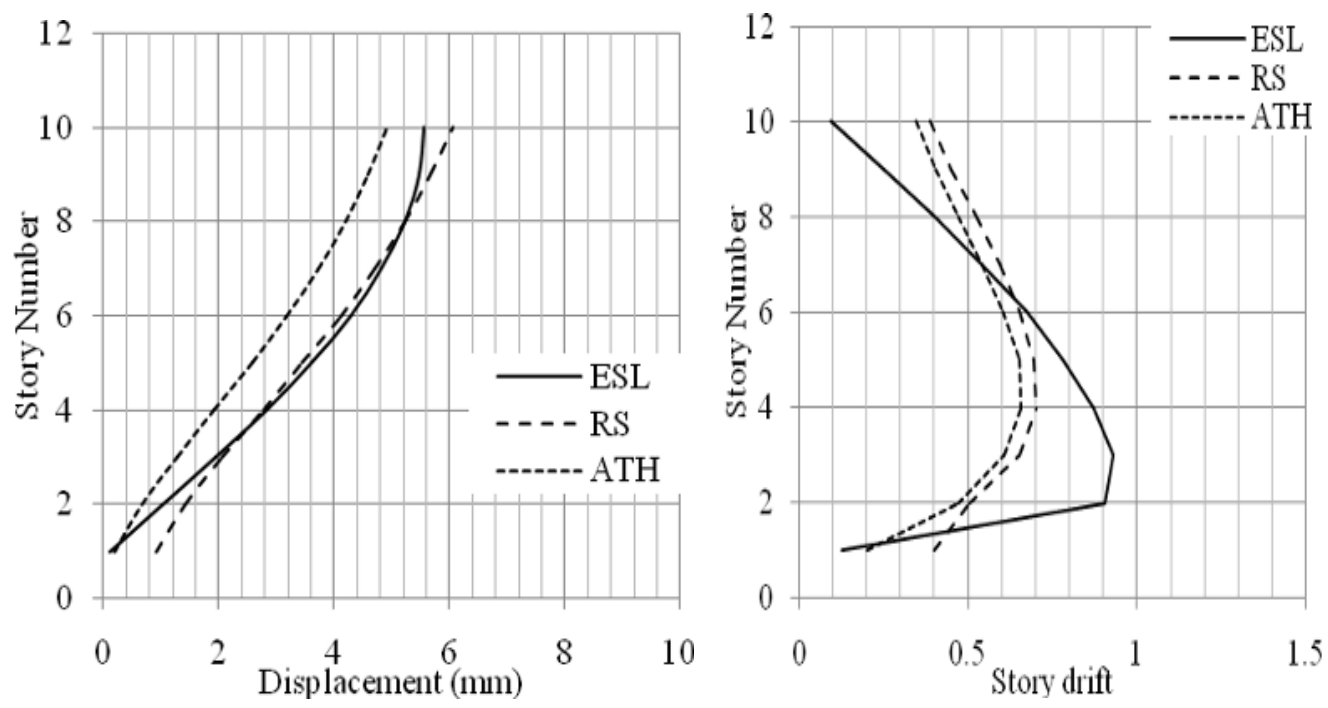

c) Model Ls6
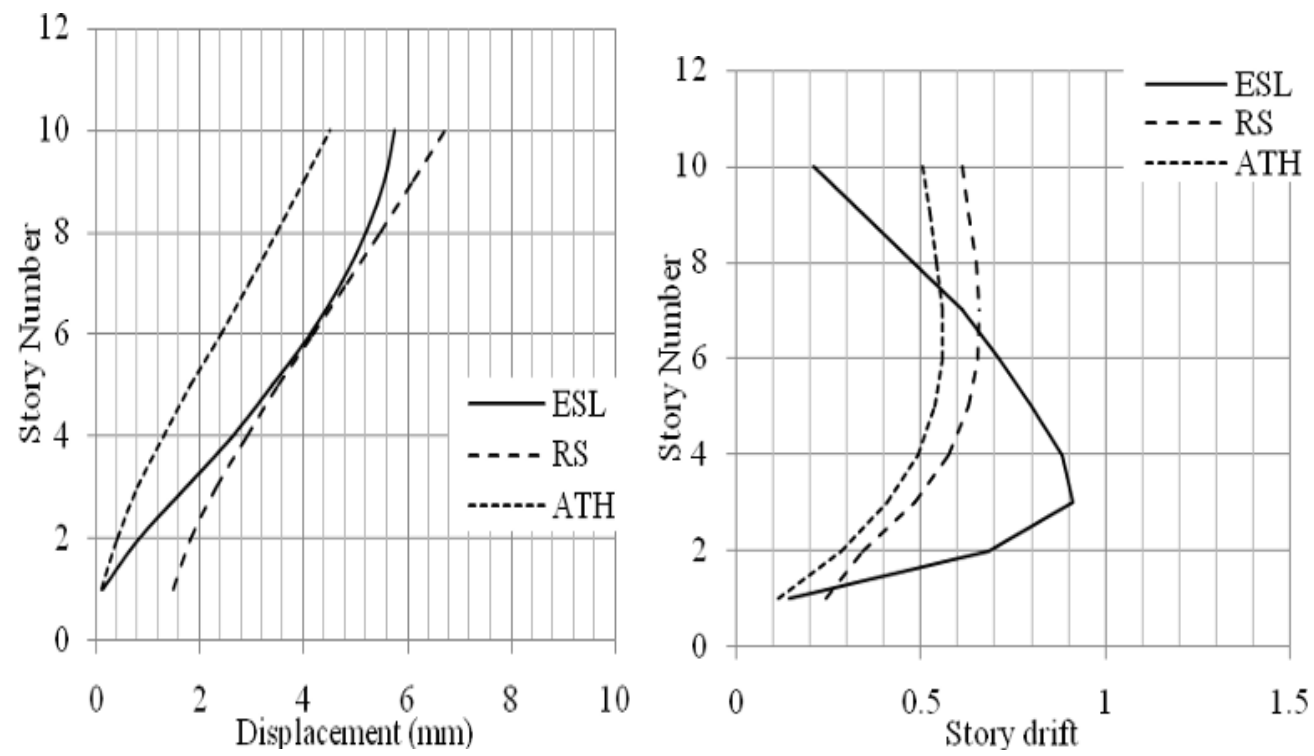

d) Model Ls7

Continue Fig. 7 Effect of lateral stiffness on displacements and story drift for 10-story models

It shall be noted that, it has been assumed that the diaphragm is rigid enough to distribute uniformly the lateral loads on the vertical elements. Therefore, the displacements and the story drifts for the external and the internal columns are the same. The following results have been observed from Figs. 6 and 7:

In 6-story and 10-story buildings, the model Ls1 displacement calculated from ESL method is larger than that calculated from RS and nonlinear ATH methods. With the increase of the lateral rigidity, (model Ls2 and model Ls3 in 6-story building and model Ls5 and model Ls6 in 10-story building), the displacement calculated from ESL 
method is almost constant. But the displacement calculated from RS and ATH methods slightly increases with the increase of lateral rigidity.

In 6-story and 10-story buildings, the tangent inclination angle of RS and ATH displacement curves and the story drift decrease with the increase of the lateral rigidity. In case of model Ls3 in 6-story building and model Ls7 in 10-story building, the story drift is almost constant and the displacement is almost linear (for 6-story building the maximum difference in the displacement value between two stories calculated from ATH method in case of model Ls3 is $22 \%$ and in case of model Ls1 is $70 \%$ ). This means, the shear distribution along the stories is almost linear (as considered in ECLF2008) in case of relatively rigid columns and it depends on the column crosssection.

\subsection{Effect of Diaphragm Rigidity on Seismic Demands}

To show the effect of the rigid diaphragm on base shear, shear distribution and story drifts, the same two 3D models, 6-story and 10-story buildings, have been analyzed with different diaphragm cross-sections. Three different models, with the same column crosssection, are used in the analysis taking into consideration the minimum safe column cross-section under effect of static and dynamic loads according to ECLF2008 (Table 4)

Table 4 Building structural element dimension for different diaphragm rigidity models

\begin{tabular}{|c|c|c|c|c|}
\hline \multicolumn{2}{|r|}{ Model } & Beam size $(\mathrm{cm})$ & Slab thickness $(\mathrm{cm})$ & Column $(\mathrm{cm})$ \\
\hline \multirow{3}{*}{$\begin{array}{l}\overrightarrow{0} \\
\frac{0}{0} \\
b \\
b\end{array}$} & Model D1 & $30 \times 50$ & 15 & $45 \times 45$ \\
\hline & Model D2 & $30 \times 80$ & 20 & $45 \times 45$ \\
\hline & Model D3 & $30 \times 100$ & 30 & $45 \times 45$ \\
\hline \multirow{3}{*}{$\begin{array}{l}\overrightarrow{0} \\
\stackrel{0}{0} \\
0 \\
0\end{array}$} & Model D4 & $30 \times 50$ & 15 & $60 \times 60$ \\
\hline & Model D5 & $30 \times 80$ & 20 & $60 \times 60$ \\
\hline & Model D6 & $30 \times 100$ & 30 & $60 \times 60$ \\
\hline
\end{tabular}

\subsubsection{Natural Vibration Analysis:}

Table 5 shows the fundamental period calculated from the $3 \mathrm{D}$ model analyzed and ECLF2008 and other international building codes. Table 5 shows that, there is no significant difference between the 3D model and the ECLF2008 fundamental periods (the maximum difference between the fundamental periods is less than $18 \%$ for all cases). Table 5 shows also that, the nearest fundamental period calculated from an empirical expressions to the 3D model among the international building codes is the ECLF2008 and EC8. This means the empirical formula adopted in the ECLF2008 is convenient for all diaphragm rigidity models and the change in the diaphragm rigidity has no significant effect on the fundamental period.

\subsubsection{Base Shear Demands for Different Diaphragm Rigidity Models}

The base shear for the different six models calculated from the three method of analysis for both 6-story and 10-story buildings are shown in Fig. 8, and the following results have been observed: 
Table 5 Estimation of the fundamental period of the building for different diaphragm rigidity models

\begin{tabular}{|l|l|c|c|c|c|c|c|}
\hline \multirow{2}{*}{ Code } & \multirow{2}{*}{ Period, $T$} & \multicolumn{6}{|c|}{ 6-story } \\
\cline { 3 - 8 } & & $\begin{array}{c}\text { Model } \\
\text { D1 }\end{array}$ & $\begin{array}{c}\text { Model } \\
\text { D2 }\end{array}$ & $\begin{array}{c}\text { Model } \\
\text { D3 }\end{array}$ & $\begin{array}{c}\text { Model } \\
\text { D4 }\end{array}$ & $\begin{array}{c}\text { Model } \\
\text { D5 }\end{array}$ & $\begin{array}{c}\text { Model } \\
\text { D6 }\end{array}$ \\
\hline $\begin{array}{l}\text { 3D model natural vibration } \\
\text { analysis, fundamental } \\
\text { mode }\end{array}$ & 0.796 & 0.694 & 0.542 & 1.181 & 0.911 & 0.888 \\
\hline $\begin{array}{l}\text { ECLF2008 } \\
{[2]}\end{array}$ & $\begin{array}{l}T_{c}= \\
0.075 H^{3 / 4}\end{array}$ & 0.655 & 0.655 & 0.655 & 0.961 & 0.961 & 0.961 \\
\hline $\begin{array}{l}\text { ECLF 92 } \\
{[14]}\end{array}$ & $T=0.1 N$ & 0.6 & 0.6 & 0.6 & 1 & 1 & 1 \\
\hline IBC [15] & $\begin{array}{l}T=0.03 \\
H^{3 / 4}\end{array}$ & 0.262 & 0.262 & 0.262 & 0.385 & 0.385 & 0.385 \\
\hline UBC 97 [16] & $\begin{array}{l}T=0.02 \\
H^{3 / 4}\end{array}$ & 0.175 & 0.175 & 0.175 & 0.256 & 0.256 & 0.256 \\
\hline EC8 [17] & $\begin{array}{l}T=0.075 \\
H^{3 / 4}\end{array}$ & 0.655 & 0.655 & 0.655 & 0.961 & 0.961 & 0.961 \\
\hline $\begin{array}{l}\text { NBCC2005 } \\
{[18]}\end{array}$ & $\begin{array}{l}T=0.05 \\
H^{3 / 4}\end{array}$ & 0.437 & 0.437 & 0.437 & 0.641 & 0.641 & 0.641 \\
\hline
\end{tabular}

Note: $H$ is the building height above the foundation level and $N$ is the number of the stories.

The increase of the diaphragm rigidity increases the total base shear. But for the six different models, in spite of the fundamental period calculated from the empirical formula adopted in ECLF2008 and the 3D model is almost the same, the base shear calculated from ESL method is significantly larger than that calculated from RS and ATH methods. That means, the base shear calculated from ESL method is conservative.

The base shear calculated from the nonlinear time history records (TH1, TH2 and TH3), for the six models, is significantly smaller than that calculated from ESL and RS methods. That means the actual base shear on the buildings is smaller than the base shear calculated from the ECLF2008.

In 6-story and 10-story buildings, the tangent inclination of the ESL curve is not equal to the tangent inclination of the RS and the three nonlinear THs curves. Once the ESL method is a function of the building weight only, this change in tangent inclination approves that the RS and the TH methods are not functions only on the building weight, but there are other factors which affect on the building base shear. 


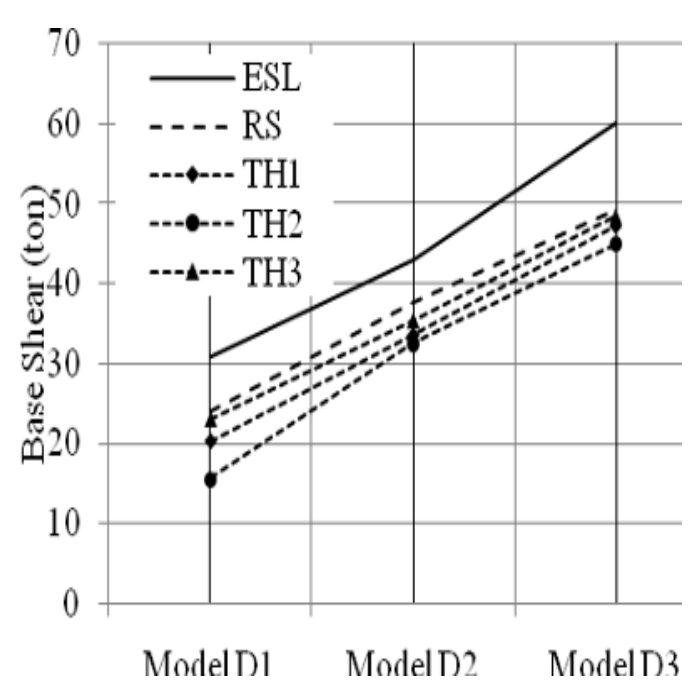

a) 6-story

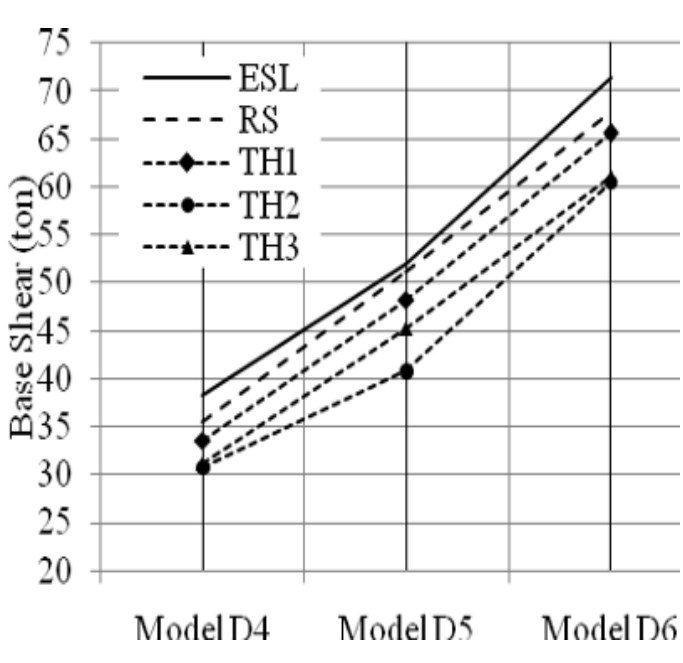

b) 10-story

Fig. 8 Diaphragm rigidity effect on base shear demand for different models

\subsubsection{Effect of Diaphragm Rigidity on Displacement and Drift Demands:}

To show the effect of the diaphragm rigidity on the shear distribution, the displacements and the story drifts in case of 6-story and 10-story buildings have been calculated using the three different methods of analysis (Figs. 9 and 10) and the following observations have been noted:

In all models of 6-story and 10-story buildings, the displacement calculated from the ESL method is significantly larger than the displacement calculated from the RS and nonlinear ATH methods. This difference increases with the increase of the diaphragm rigidity (e.g. the maximum difference between ESL and ATH displacement in model D1 is $21 \%$ but the maximum difference between the two methods in model D3 is $42 \%$ ). Also, in all models of 6-story and 10-story buildings, the displacement calculated from RS and ATH methods are close.

In case of the RS and the ATH methods, the tangent inclination of the displacement curve and the curvature of the story drift in case of the relatively flexible diaphragm, model D1 in 6-story building and model D4 in 10-story building, are significantly larger than the tangent inclination of the displacement curve and the curvature of the story drift in case of relatively rigid diaphragm, model D2 and model D3 in 6-story building and model D5 and model D6 in 10-story building. This means, the change in the diaphragm rigidity has a significant effect on the shear distribution and the floor displacement. In the contrary, the tangent inclination of the displacement curve and the curvature of the story drift for ESL are almost constant for all models. Therefore, ESL method non-significantly affected by the diaphragm rigidity. 

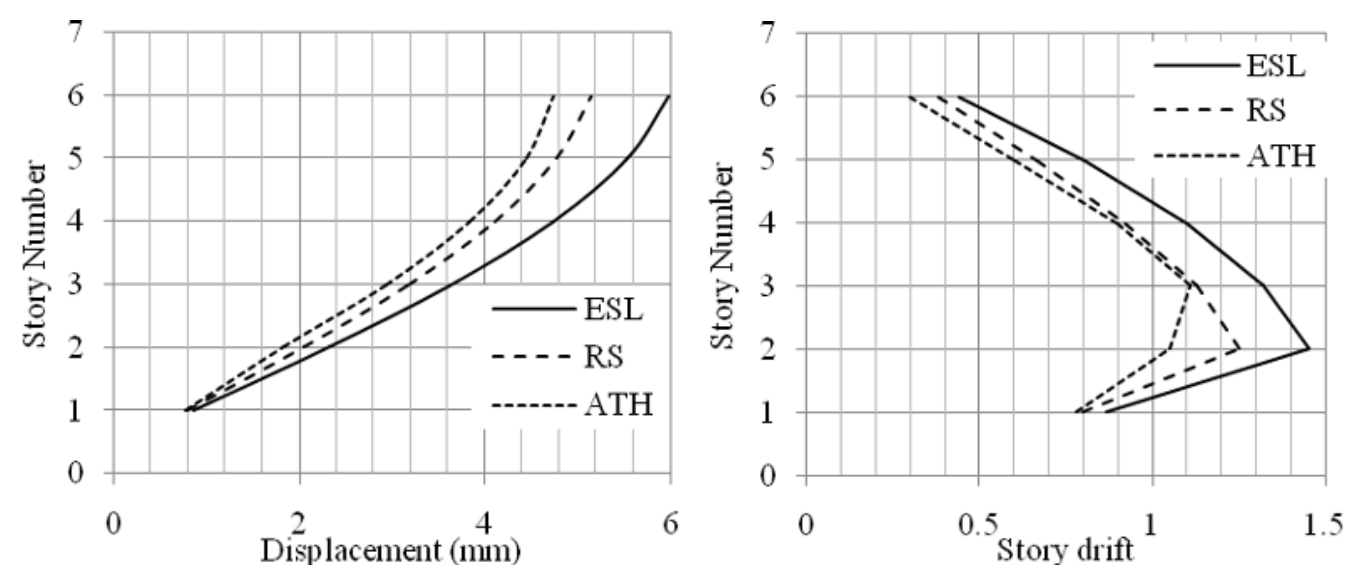

a) Model D1

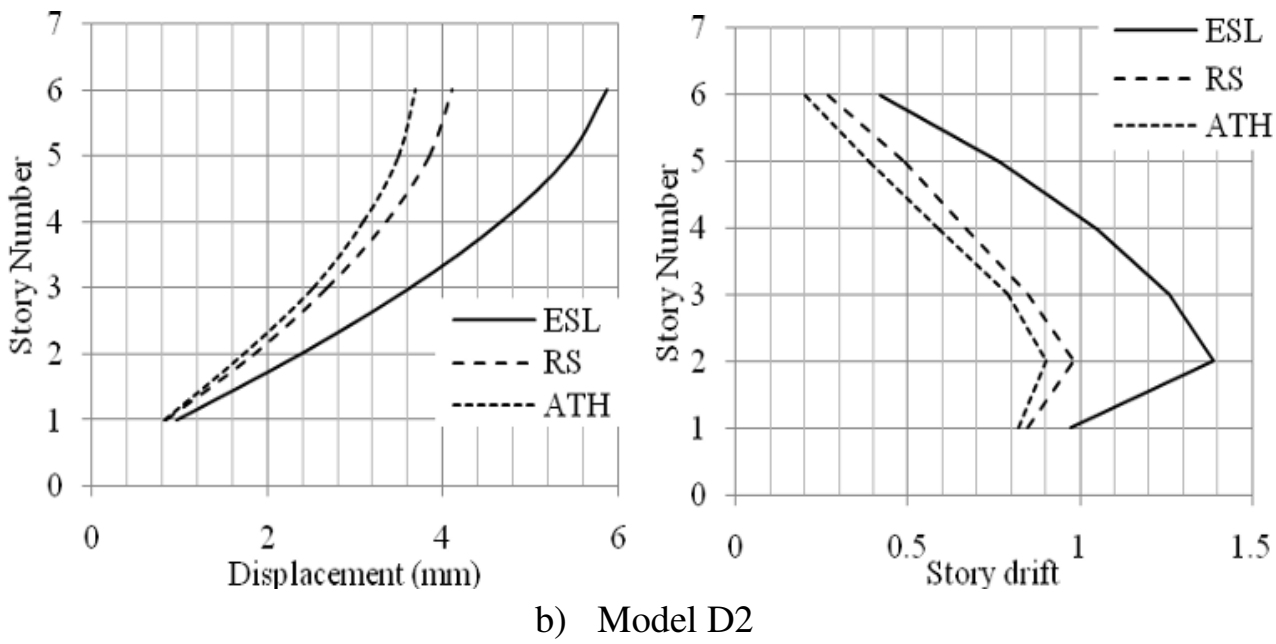

Fig. 9 Effect of diaphragm rigidity on displacements and story drifts for 6-story building
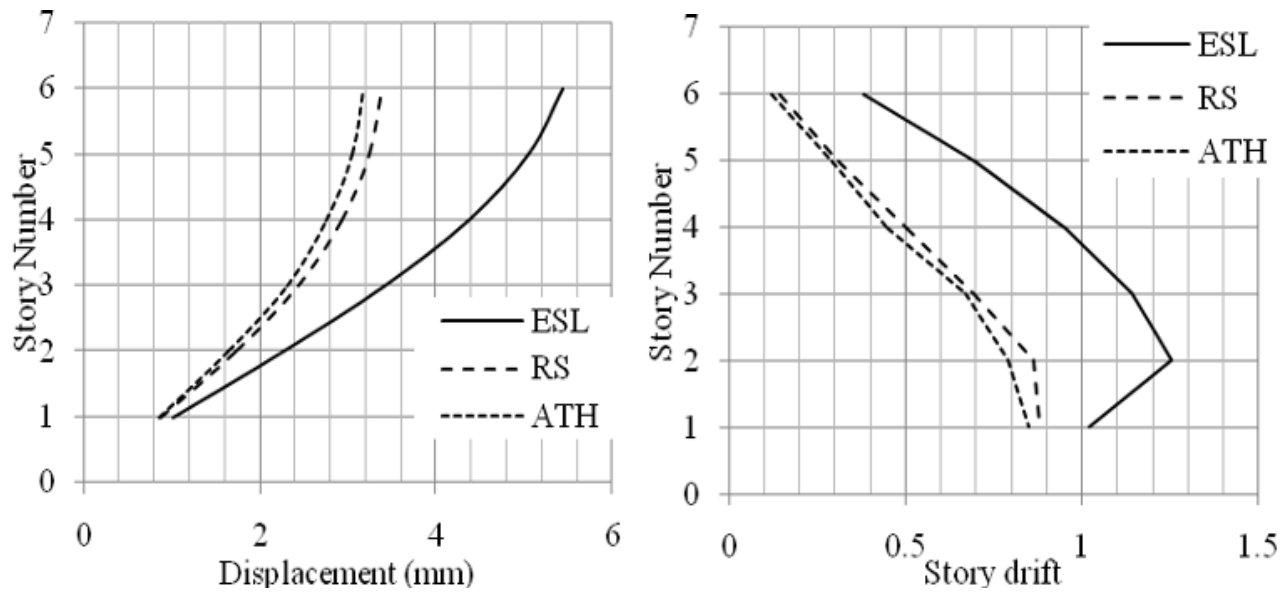

c) Model D3

Continue Fig. 9 Effect of diaphragm rigidity on displacements and story drifts for 6-story building 

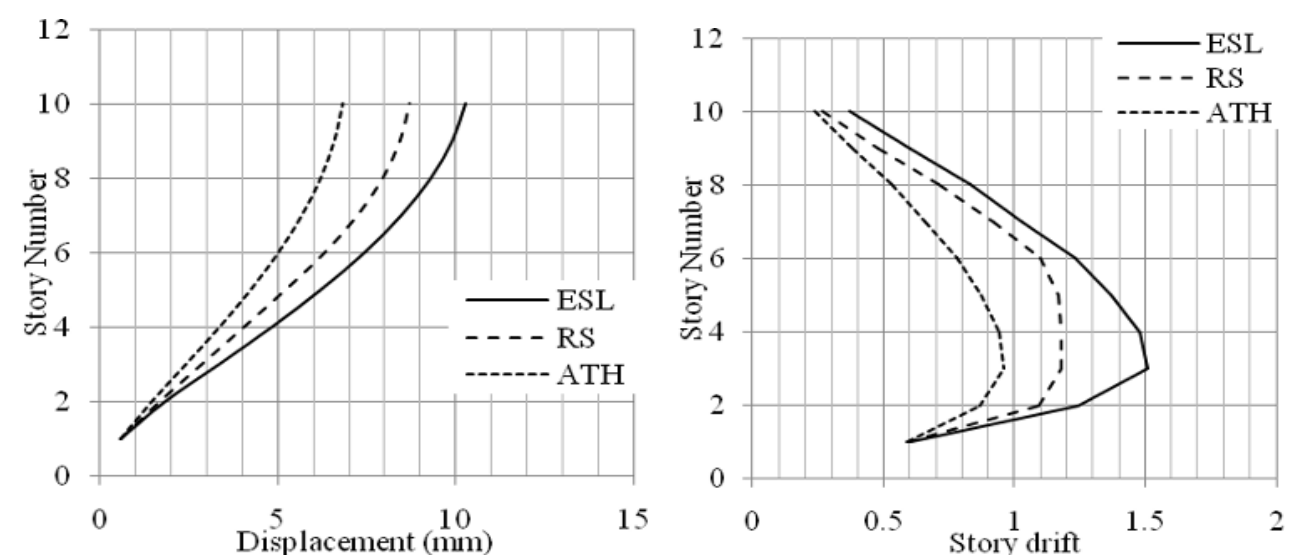

a) Model D4
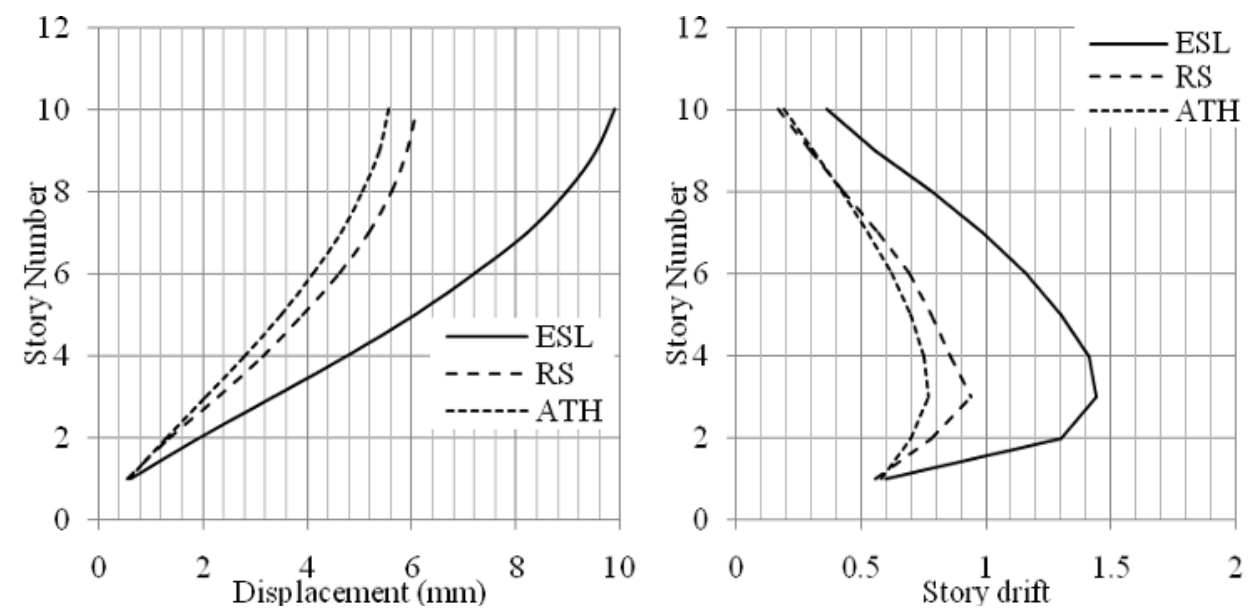

b) Model D5

Fig. 10 Effect of diaphragm rigidity on displacements and story drifts for 10-story building
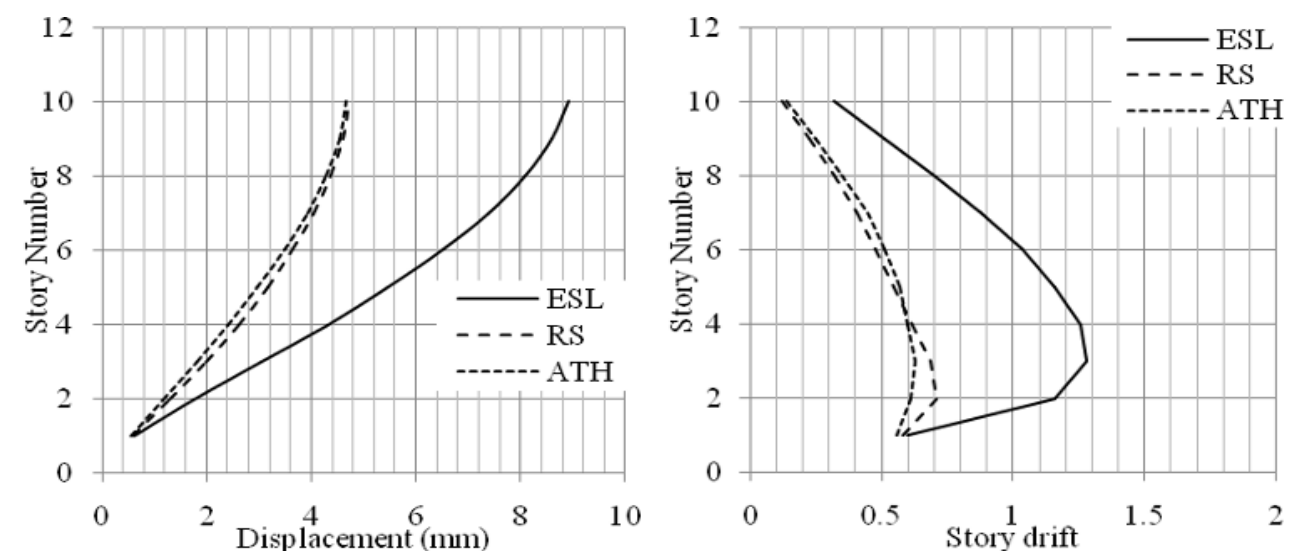

c) Model D6

Continue Fig. 10 Effect of diaphragm rigidity on displacements and story drifts for 10-story building 


\section{SUMMARY AND CONCLUSION}

In this study, nonlinear time history (TH) analysis, for different three time history records, has been used to evaluate the equivalent static load (ESL) and the response spectrum (RS) methods, which adopted in the Egyptian code for load and forces (ECLF2008).

The main findings of the study are summarized as follows:

1. ECLF2008's empirical expression for calculating the fundamental period of vibration gives almost the same fundamental period calculated from the structural model in case of relatively flexible column. But the increase in lateral rigidity decreases the fundamental period for the structural model, and the fundamental period calculated from empirical expression is constant. This means the fundamental period is not only a function of building height but also a function of lateral rigidity.

2. ECLF2008's empirical expression for calculating the fundamental period of vibration gives almost the same fundamental period calculated from the structural model in case of flexible and rigid diaphragm. This means the change in diaphragm rigidity has no significant effect on the fundamental period of vibration.

3. The increase of the lateral and/or diaphragm rigidity increases the total building base shear. But the increase of RS and/or nonlinear TH base shear is different from that increase of ESL base shear, which depends only on the building weight. That means the base shear is not only a function of the building weight but also a function of the building rigidity.

4. The nonlinear TH base shear, in all studied models, is smaller than the RS and/or ESL base shear. This means the ECLF2008 empirical expressions for calculating base shear is overestimated.

5. The displacements and story drifts calculated from ESL method non-significantly change with the change of the column and/or diaphragm rigidity. On the contrary, the displacements and story drifts calculated from RS and/or nonlinear TH methods change more significantly with the change of the lateral and/or diaphragm rigidity. This means the linear shear distribution assumed in ECLF2008 is not adequately accurate and depends on the building rigidity.

\section{REFRENCES}

[1] Hossam S. Badawi and Sherif A. Mourad, 1994 "Observations from the 12 October 1992 Dahshour earthquake in Egypt", Natural Hazards journal, Vol. 10, No. 3, November, pp261-274.

[2] Housing and Building National Research Center, Egyptian Code for Load and Forces (ECLF2008), November 2008 edition, Cairo, Egypt.

[3] Paz, M., "Structure Dynamics Theory and Computation" $3^{\text {rd }}$ edition, Van Nostrand Reinhold, New York, USA

[4] S.K. Ghosh and David A. Fanella, July 2004 "Seismic and Wind Deign of Concrete Buildings" Third edition, USA

[5] Computers and Structures (2003), "SAP2000: Integrated Software for Structural Analysis and Design", Computers and Structures, Inc. (http://csiberkeley.com), Berkeley, CA, U.S.A. 
[6] Egyptian code for Design and Construction the Reinforced Concrete Building (ECP 203-2007), 2007

[7] Computers and Structures, Inc (CSI), SAP2000 Tutorial Manuals (1998), Berkeley, California

[8] Chopra AK, (1995) "Dynamics of Structures Theory and Application to Earthquake Engineering", University of California at Berkeley, USA

[9] Sashi K. Kunnath and Erol Kalkan (March 2004), "Evaluation of Seismic Deformation Demands Using Non-linear Procedures in Multistory Steel and Concrete Moment Frames" ISET Journal of Earthquake Technology, Paper No. 445, Vol. 41, No. 1, pp. 159-181

[10] "http://www.vibrationdata.com" El Centro University.

[11] "http://peer.berkeley.edu" Regents of the University of California.

[12] SAP2000 Advanced 12.0.0, Structural Analysis Program, Computer and Structures, Inc.

[13] M. Panneton, P. Léger, and R. Tremblay (September 2006), "Nonlinear analyses of a reinforced concrete shear wall building according to the National Building Code of Canada 2005", NRC Research Press, http://cjce.nrc.ca

[14] Housing and Building National Research Center, Egyptian Code for Load and Forces (ECLF1993), November 1993 edition, Cairo, Egypt.

[15] IBC, International Building Code International Code Council, INC., February 2009 edition, 4051 West Flossmoor Road, Country Club Hills, USA

[16] UBC97, Uniform Building Code, International Council of Building Officials, 1997, Whittier, California

[17] EC8 [2003] European Committee for Standardization, prEN-1998-1, Eurocode No. 8, Design of Structures for Earthquake Resistance, Part 1: "General Rules, Seismic Actions and Rules for Buildings", Brussels.

[18] NBCC 2005, National Building Code of Canada. 12th ed, Canadian Commission on Building and Fire Codes, National Research Council of Canada (NRCC), Ottawa, Ont.

[19] Housing and Building National Research Center, Egyptian Code for Designing and Constructing Reinforced Concrete Structures (ECP 203-2007), 2007 edition, Cairo, Egypt. 


\section{تقييم الأداء الزلزالي للمنشآت متعددة الطوابق والمصممة طبقاً للكود المصري"}

خالد أحمد عبد الرحيم ، شحاته الضبع عبد الرحيم ، حسني محمود صغير ، محمود حسين أحمد

تستخدم عدة طرق من التحليل لحساب الردود الزلزالية للمنشآت. وتتفاوت كل طريقة من هذه الطرق

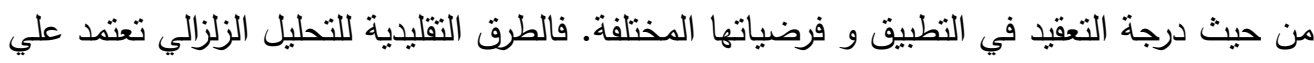
استخدام الحمل الأستاتيكي المكافئ كحمل زلزالي بينما هناك اتجاهات لزيادة التأكيد علي استخدام

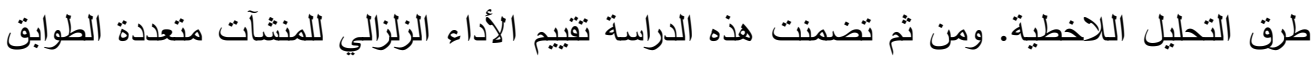

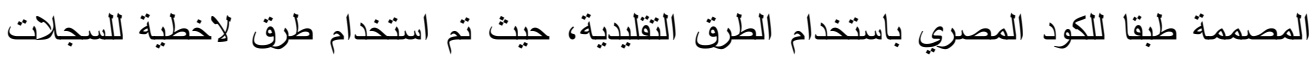
الزمنية في التحليل لتقيم الطريقتين الواردتين في الكود المصري لحساب الأحمال علي المنشآت وهما

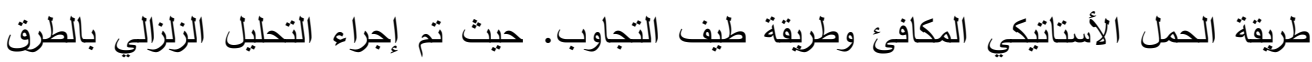

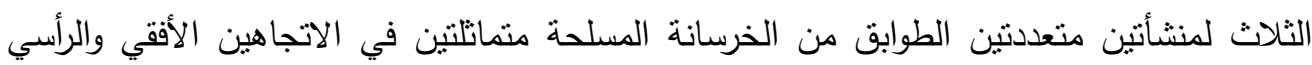

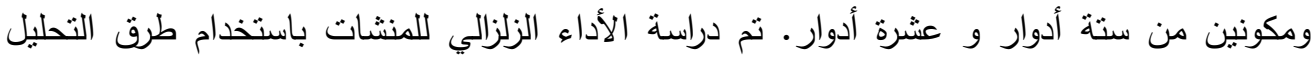

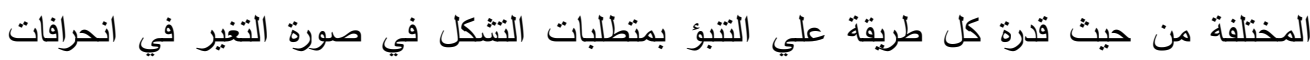

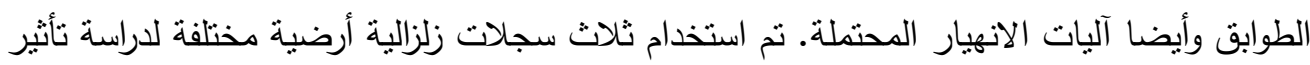

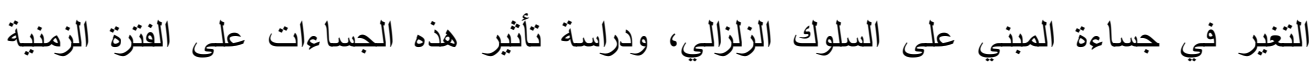

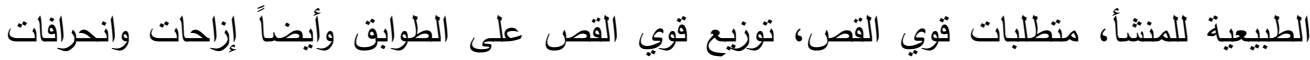
الطوابق.

أوضحت النتائج أن الأداء الزلزالي لكل طريقة من الطرق المستخدمة في التحليل له سلوك مختلف

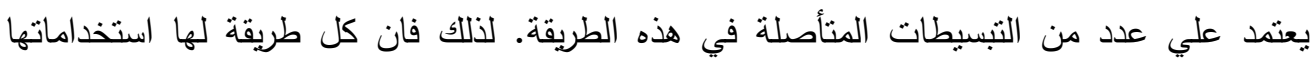
ونقائصها التي يجب أن تأخذ في الاعتبار عند اختيار الطريقة المناسبة لحساب التأثير الزلزالي لمنشأ

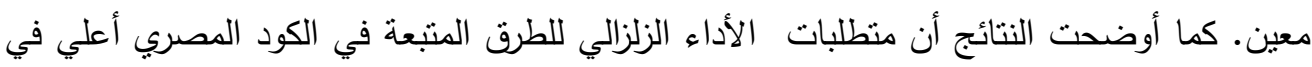

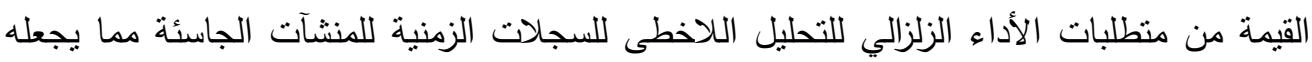

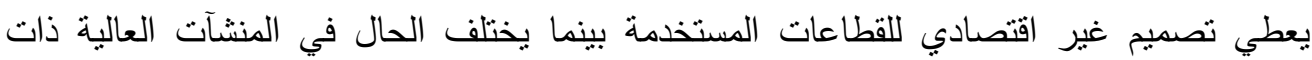
الجساءة المنخفضة كما هو الحال للمباني العالية والتي يجب استخدام حساب منطلبات الاداء الزلزالي بالتحليل اللاخطي. 